\title{
Protective role of phenylethanoid glycosides, Torenoside B and Savatiside A, in Alzheimer's disease
}

\author{
SHILIANG JI ${ }^{1}$, SHANSHAN $\mathrm{LI}^{2}$, XINGXING ZHAO ${ }^{3}$, NAIXIN KANG $^{4}, \mathrm{KEKE} \mathrm{CAO}^{5}$, YINGYING ZHU ${ }^{6}$, \\ PANPAN PENG ${ }^{4}, \mathrm{JING} \mathrm{FAN}^{4}$, QIONGMING XU ${ }^{4}$, SHILIN YANG ${ }^{4,7}$ and YANLI LIU ${ }^{4}$ \\ ${ }^{1}$ Department of Pharmacy, Suzhou Science and Technology Town Hospital, Suzhou Hospital Affiliated to Nanjing Medical \\ University; ${ }^{2}$ Patent Examination Cooperation (Jiangsu) Center of the Patent Office, SIPO; ${ }^{3}$ Department of Neonatology, \\ Suzhou Municipal Hospital, The Affiliated Suzhou Hospital of Nanjing Medical University; ${ }^{4}$ College of \\ Pharmaceutical Science, Soochow University, Suzhou, Jiangsu 215000; ${ }^{5}$ Shenzhen Yuanxing Gene-Tech Co., Ltd., \\ Shenzhen, Guangdong 518000; ${ }^{6}$ Suzhou Yihua Biomedical Technology Co., Ltd., Suzhou, Jiangsu 215000; \\ ${ }^{7}$ Jiangxi University of Traditional Chinese Medicine, Nanchang, Jiangxi 330004, P.R. China
}

Received May 29, 2018; Accepted February 26, 2019

DOI: $10.3892 /$ etm.2019.7355

\begin{abstract}
The current study assessed the efficacy of two phenylethanoid glycosides (PhGs), Torenoside B (TB) and Savatiside A (SA), in the treatment of Alzheimer's disease (AD). The effects of TB and SA compounds were first assessed following amyloid beta $(\mathrm{A} \beta)_{25-35}$ induction in SH-SY5Y cells at a range of concentrations. Their effects on cell viability and reactive oxygen species (ROS) were determined by performing MTT and dichlorofluorescin diacetate assays, respectively. The concentration of intracellular $\mathrm{Ca}^{2+}$ was determined using Fluo-3AM to stain SH-SY5Y cells. SA and TB treatments were also assessed in $\mathrm{A} \beta_{25-35}$-induced mice. Y-maze and Morris water maze methods were utilized to assess murine learning and memory capability. The pathological changes of murine hippocampi was determined using H\&E and Nissl staining. In addition, biochemical parameters associated with intracellular reactive oxygen pathways including Maleic dialdehyde (MDA), superoxide dismutase (SOD), glutathione peroxidase (GSH-Px), acetylcholinesterase (AChE) and Calnexin were also assessed. TB and SA treatment in $A \beta_{25-35}$-induced SH-SY5Y cells resulted in the restoration of cell morphology, an increase of
\end{abstract}

Correspondence to: Professor Yanli Liu, College of Pharmaceutical Science, Soochow University, 199 Renai Road, Suzhou, Jiangsu 215000, P.R. China

E-mail: liuyanli_suda@163.com

Abbreviations: PhGs, phenylethanoid glycosides; TB, Torenoside B; SA, Savatiside A; Gal, Galantamine; AD, Alzheimer's disease; ROS, reactive oxygen species; A $\beta$, amyloid-beta; MDA, Maleic dialdehyde; SOD, superoxide dismutase; GSH-Px, glutathione peroxidase; AchE, acetylcholinesterase; H\&E, hematoxylin and eosin; TEM, transmission electron microscope

Key words: phenylethanoid glycosides, Torenoside B, Savatiside A, Alzheimer's disease, amyloid-beta, oxidative stress, learning and memory capabilities
SOD and GSH-Px activity, a decrease in ROS, $\mathrm{Ca}^{2+}$ and MDA content, and a decrease in Calnexin expression. Furthermore, SA or TB treatment administered to $A \beta_{25-35}$-induced mice improved their spatial/non-spatial learning and memory capabilities. The efficacy of treatment was also supported by a marked change in the morphological structure of pyramidal neurons in the CA1 areas of murine hippocampi, as well as an increase of SOD and GSH-Px activity. Treatment also resulted in a decrease in MDA content, AchE activity and Calnexin expression in murine hippocampal tissue. As potential AD treatment drugs, SA and TB compounds have been demonstrated to alleviate the oxidative stress induced by $\mathrm{A} \beta_{25-35}$ via the regulation of intracellular calcium homeostasis and Calnexin, preventing AD development.

\section{Introduction}

The incidence of Alzheimer's disease (AD) is increasing rapidly with aging populations worldwide and has given rise to a series of medical and social-economic problems (1). It has been reported that 44.35 million people were diagnosed with AD worldwide in 2013, a number which may increase and to 75.62 million by 2030 and 135.46 million by 2050 (2). Thus, the pathogenesis of $\mathrm{AD}$ and its prevention and treatment is of great importance to medical research.

$\mathrm{AD}$ is a neurodegenerative disease that frequently occurs in the senior population and is characterized by progressive dementia (2). AD has also been demonstrated to be influenced by a variety of factors (3), in which the major manifestation is the appearance of senile plaques (SP). SP is associated with the aggregation and accumulation of amyloid-beta $(A \beta)$ peptides in the cerebral cortex and hippocampus of the human brain (4). Aggregated and accumulated A $\beta$ peptides have also been reported to induce the abnormal phosphorylation of tau proteins, leading to neurofibrillary tangle formation, which serves an important role in AD pathogenesis (5). It is therefore important to determine novel drug candidates to prevent the development of $\mathrm{AD}$ and to treat patients with $\mathrm{AD}$. 
Monochasma savatieri Franch, a member of the Scrophulariaceae family, is widely distributed through certain areas of Southern China (6). It is also a traditional Chinese medicine that is used to treat many diseases, including the common cold, cough and diarrhea (6). Extracts of Monochasma savatieri Franch obtained from the Jiangsu province of China was reported to possess bioactive ingredients for treatment of the aforementioned diseases $(7,8)$. These extracts were revealed to be composed of two types of phenylethanoid glycosides (PhGs): Torenoside B (TB) and Savatiside A (SA) (6).

$\mathrm{PhGs}$ exhibit a wide range of bioactivities for the treatment of disease. For instance, they may be used as anti-immunomodulatory, anti-oxidative, anti-inflammatory, anti-bacterial, anti-tumor, and anti-influenza virus agents. They may also be used as potential drugs for kidney protection and laxative effect treatments (9). Previous studies have revealed that PhGs extracts can be used to treat a variety of coronary artery diseases (7), respiratory infections and pneumonia (10). In a recent report, $\mathrm{PhGs}$ were demonstrated to influence the structure and function of neurons and thus, may be used as neuroprotective agents against $\mathrm{H}_{2} \mathrm{O}_{2}$ and $\mathrm{A} \beta_{1-42}$-induced injury in $\mathrm{PC} 12$ cells (11). This observation is further supported by a dramatic neuroprotective effect exhibited by Forsythenethosides A and B, two PhGs extracted from Forsythia suspense, against PC12 cell damage induced by the deprivation of serum (12).

According to previous studies, PhGs are considered to be potential drug candidates for the treatment of $\operatorname{AD}(7,8,10)$. However, few reports assess the neuroprotective effect of TB and SA extracted from Monochasma savatieri Franch, in the treatment of AD as well as the signal pathways utilized. In the present study, in vitro and in vivo $\mathrm{AD}$ experimental models were constructed and the effects of TB or SA on these models were assessed. The $A \beta$ fragment 25-35 (A $\left.\beta_{25-35}\right)$, a short proteolytic fragment of the full-length $A \beta$ peptide, is known to exhibit neurotoxicity (13). This fragment was utilized as a substrate for the induction of AD in the cell and small animal models of the current AD treatment study.

\section{Materials and methods}

Materials and ethics statement. SA and TB utilized in the current study were provided by the Department of Natural Medicine Chemistry, Suzhou University (Suzhou, China) and $A \beta_{25-35}$ was obtained from BIOSS (Beijing, China). MTT was purchased from Sigma-Aldrich (Merck KGaA, Darmstadt, Germany). Galantamine (Gal) was provided by J\&K Scientific, Ltd. (Beijing, China). The SH-SY5Y cell line was purchased from the American Type Culture Collection (ATCC ${ }^{\circledR}$ CRL-2266 ${ }^{\mathrm{TM}}$; Manassas, VA, USA). All animal experiments were approved by the Animal Ethics Committee of Soochow University (Suzhou, China) and all procedures were performed in strict accordance with the protocols of the Care and Use of Laboratory Animals and related norms of the animal laboratory of Soochow University (Suzhou, China).

SH-SY5Y cell culture and treatment viability. SH-SY5Y cells were cultured in F12/MEM medium (Gibco; Thermo Fisher Scientific, Inc., Waltham, MA, USA) supplemented with $10 \%$ fetal bovine serum (Gibco; Thermo Fisher Scientific, Inc.) in an incubator with $5 \% \mathrm{CO}_{2}$ at $37^{\circ} \mathrm{C}$. After cells reached a confluence of $70-80 \%$, they were digested with $0.05 \%$ trypsin and transferred to the logarithmic growth phase. SH-SY5Y cells $\left(1 \times 10^{5}\right.$ cells $\left./ \mathrm{ml}\right)$ were then inoculated into the wells of a 96-well plate at a density of $1 \times 10^{4}$ cells/well and cultured for $24 \mathrm{~h}$ at $37^{\circ} \mathrm{C}$ in an incubator with $5 \% \mathrm{CO}_{2}$.

Cell-cultured wells were subsequently divided into the $\mathrm{A} \beta_{25-35}$ induced group, the $\mathrm{A} \beta_{25-35}+\mathrm{SA}$ treated group, the $\mathrm{A} \beta_{25-35}+\mathrm{TB}$ treated group and the blank group (utilized as a control). Cultured cells were pretreated with 25,50 and $100 \mu \mathrm{M}$ of SA or TB, and were induced with $30 \mu \mathrm{M} \mathrm{A} \beta_{25-35}$ for $24 \mathrm{~h}$. An MTT assay was then performed to assess the viability of cells following SA and TB treatments. A total of $10 \mu 15 \mathrm{mg} / \mathrm{ml}$ MTT was added into wells and incubated for $4 \mathrm{~h}$ at $37^{\circ} \mathrm{C}$. The supernatant in the well was removed and $100 \mu \mathrm{l}$ of dimethyl sulfoxide (DMSO) was added. The plate was then incubated for $10 \mathrm{~min}$ at room temperature and a fully-automatic microplate reader was utilized to measure the absorbance at a wavelength of $570 \mathrm{~nm}$ [optical density $(\mathrm{OD})_{570 \mathrm{~nm}}$ ]. The wells of the control group were cultured as aforementioned, except with the same volume of 1x PBS buffer instead of the assessed PhGs. Cell viability was calculated using the following formula: Cell viability rate $\%=\left(\mathrm{OD}_{570 \mathrm{~nm} \text { (experiment group) }} / \mathrm{OD}_{570 \mathrm{~nm} \text { (normal group) }}\right)$ $\mathrm{x} 100 \%$. Measurements for each sample were performed in triplicate to achieve the deviation.

Assessment of SH-SY5Y morphological changes. Following the manufacturer's protocol, the Gimesa assay kit (Nanjing Jiancheng Bioengineering Institute, Nanjing, China) was utilized for the staining of SH-SY5Y cells with or without the SA and TB treatments. Stained cells were then rinsed with water and air dried at room temperature. An inverted optical microscope (Eclipse TE2000-U; Nikon Corporation, Tokyo, Japan; magnification, x400) was used to observe the morphology of SH-SY5Y cells. Images were obtained using Olympus Image-ProPlus 6.0 (Olympus Corporation, Tokyo, Japan). The morphological changes of treated SH-SY5Y cells were compared with the control group.

Detection of reactive oxygen species (ROS). Suspended cells $\left(1 \times 10^{5}\right.$ cells $\left./ \mathrm{ml} ; 2 \mathrm{ml}\right)$ were seeded in 6 -well plates and cultured for $24 \mathrm{~h}$ in an incubator at $37^{\circ} \mathrm{C}$ with $5 \% \mathrm{CO}_{2}$. Wells were grouped into treatment and control groups as aforementioned. Subsequently, the medium was removed and cells were washed once with 1x PBS buffer. A dichlorofluorescin diacetate (DCFH-DA) assay was then performed to measure the ROS content in cells. Serum-free F12/MEM medium (200 $\mu \mathrm{l}$ ) containing $10 \mu \mathrm{M}$ DCFH-DA (Beyotime Institue of Biotechnology, Hiamen, China) was added to each well of the 6-well plate. Cells were then incubated for $10 \mathrm{~min}$ at room temperature, washed once with $1 \mathrm{x}$ PBS and digested with $0.05 \%$ trypsin to obtain the suspension. Suspended cells were recovered via centrifugation at $12,000 \mathrm{x}$ g for $15 \mathrm{~min}$ at $4^{\circ} \mathrm{C}$ and washed twice with 1x PBS. Cells were subsequently suspended in 1x PBS buffer with a final volume of $300 \mu 1$. ROS content was measured using a flow cytometer (Beckman Coulter, Inc., Brea, CA, USA) with an excitation wavelength at $488 \mathrm{~nm}$ and emission at $525 \mathrm{~nm}$. Immunofluorescence signals were also quantified by ImageJ software v1.8.0 (National Institutes of Health, Bethesda, MD, USA) ROS content in all groups were obtained. 
Detection of $\mathrm{Ca}^{2+}$ concentration. Cell $\mathrm{Ca}^{2+}$ concentration was measured using the $\mathrm{Ca}^{2+}$ Fluo-3AM (Beyotime Institute of Biotechnology) staining kit. SH-SY5Y cells were cultured in a 6-well plate as aforementioned. Prior to cell staining, culture medium was removed from wells and cells were washed once with 1x PBS buffer. PBS solution (1x; $5 \mathrm{ml}$ ) with $5 \mu \mathrm{M} \mathrm{Ca}^{2+}$ Fluo-3AM was added to each well and incubated for $30 \mathrm{~min}$ at $37^{\circ} \mathrm{C}$. PBS solution was removed and wells were washed once with 1x PBS buffer to remove extra dye. Cells were then digested with $0.05 \%$ trypsin and collected via centrifugation at $12,000 \mathrm{x} \mathrm{g}$ for $15 \mathrm{~min}$ at $4^{\circ} \mathrm{C}$. Subsequently, cells were suspended in 1x PBS buffer. Upon excitation at $506 \mathrm{~nm}$, the fluorescence intensity of suspended cells was measured at $526 \mathrm{~nm}$ using a flow cytometer. Fluorescence intensity was then used to estimate the concentration of $\mathrm{Ca}^{2+}$.

Quantification detection of apoptosis. For flow cytometric analysis, Hippocampal neurons were collected and diluted with PBS. Apoptosis was measured via flow cytometry using the Annexin V-EGFP/PI Apoptosis Detection kit (Beyotime Institute of Biotechnology) according to the manufacturer's protocol. Cell suspensions $(100 \mu \mathrm{l})$ were added to $100 \mu \mathrm{l}$ annexin $\mathrm{V}$ and $10 \mu \mathrm{l} \mathrm{PI}$, incubated for $20 \mathrm{~min}$ at room temperature and analyzed using the MUSE cell analyzer (EMD Millipore, Billerica, MA, USA).

Western blot analysis. Western blotting was utilized to measure the expression of protein in cells. Proteins were extracted from cells using a cell lysate (radioimmunoprecipitation assay buffer) and then determined using a modified Folin-Ciocalteu assay. Samples $(20 \mu \mathrm{g})$ were then denatured using $10 \%$ sodium dodecyl sulfate and then run on a $12 \%$ SDS-PAGE. Subsequently, samples were transferred to a polyvinylidene difluoride membrane (EMD Millipore) and rinsed with TRIS-buffered saline with $0.5 \%$ Tween-20 for 5 min. Membranes were immersed in 5\% Bovine Serum Albumin (cat. no. 0332; Sangon Biotech Co., Ltd., Shanghai, China) for $2 \mathrm{~h}$ at room temperature, washed with 1x PBS buffer. Anti-Calnexin (1:500; rabbit polyclonal antibody; cat. no. 2433; Cell Signaling Technologies, Inc., Danvers, MA, USA) and anti- $\beta$-actin (mouse monoclonal antibody; cat. no. 3700; Cell Signaling Technology, Inc.) antibodies were diluted with PBST $(1: 5,000)$, then incubated overnight at $4^{\circ} \mathrm{C}$. Membranes were subsequently washed with TBST buffer for $3 \times 15$ min and then immersed in 1x PBS buffer. Horseradish peroxidase-conjugated sheep anti-mouse and anti-rabbit antibodies (anti-mouse cat. no. NA931; anti-rabbit cat. no. NA934V; each, 1:3,000; GE Healthcare, Chicago, IL, USA) were subsequently added to the solution and incubated for $1 \mathrm{~h}$ at $37^{\circ} \mathrm{C}$. Samples were kept in the dark to avoid exposure to light. Membranes were then washed with TBST buffer for 3x10 min. The density of each protein band was visualized with an ECL detection kit (Thermo Fisher Scientific, Inc.) and quantified using SigmaScan-pro V5.01 (SPSS, Inc., Chicago, IL, USA). The results were used to evaluate the expression of protein in cells.

Animal model construction. A total of 15 male Institute of Cancer Research mice (clean grade; 6-8 weeks; weight, 18-22 g) were obtained from Shanghai SLAC Laboratory
Animal Co., Ltd. (Shanghai, China). Animals were housed in a quiet laboratory at a controlled temperature of $22 \pm 2{ }^{\circ} \mathrm{C}$ and a humidity of $50 \pm 10 \%$ with free access to food and water, under a $12 \mathrm{~h}$ light/dark cycle. Mice were randomly divided into 5 groups (each, $n=3$ ): The blank control, the $A \beta_{25-35}$, the $\mathrm{Gal}+\mathrm{A} \beta_{25-35}$, the $\mathrm{SA}+\mathrm{A} \beta_{25-35}$ and the $\mathrm{TB}+\mathrm{A} \beta_{25-35}$ group.

Mice in the treatment groups were administered a pre-injection via the caudal vein for 7 consecutive days with the following agents at various dosages: Gal, $3 \mathrm{mg} / \mathrm{kg} / \mathrm{d}, \mathrm{SA}$, $100 \mathrm{mg} / \mathrm{kg} / \mathrm{d}$ and TB, $100 \mathrm{mg} / \mathrm{kg} / \mathrm{d}$. Mice of the control group and the $\mathrm{A} \beta_{25-35}$ group were injected with $10 \mu \mathrm{l}$ saline. The experimental procedure was in accordance with a previous study (14). On the 8th day, following anesthetization, mice were secured on a stereotaxic instrument. A $10 \mu 1$ microsyringe was vertically inserted $2.46 \mathrm{~mm}$ posterior to the bregma, at a $2 \mathrm{~mm}$ lateral and $2 \mathrm{~mm}$ depth under the cortical surface. Mice in the $A \beta_{25-35}$ treatment groups were injected with $3 \mu \mathrm{l}$ of $\mathrm{A} \beta_{25-35}$ solution $(3.4 \mu \mathrm{g} / \mu \mathrm{l})$, while mice in the control group received an equal volume of normal saline. The injection speed was kept constant at $1 \mu \mathrm{l} / \mathrm{min}$ and was performed according to the previous study (15). Needles were retained for $>5 \mathrm{~min}$ and then slowly withdrawn by $1 \mathrm{~mm}$. According to a previous and to personal experience, the volume of injection to the hippocampus does not result in extensive/non-specific neuronal damage (14).

Following surgery, injured mice were kept warm (at $37^{\circ} \mathrm{C} \pm 2^{\circ} \mathrm{C}$ ) until their conscious recovery and were then housed under a constant temperature $\left(22^{\circ} \mathrm{C} \pm 2^{\circ} \mathrm{C}\right)$. Following $24 \mathrm{~h}$, mice in the treatment groups were administered intravenous SA, TB or Gal (a routine drug for the treatment of learning and memory disorder). Mice in the control and $A \beta_{25-35}$ induced groups were injected with $10 \mu 1$ vehicle (saline). On the 18th day, all mice participated in behavioral experiments. Histopathological changes of hippocampal morphology and neuronal ultra-structures, and the changes of relative biochemical parameters were subsequently assessed.

$Y$-maze test. Following the last drug administration, mice were subjected to the Y-maze test for the assessment of spatial recognition memory, as previously described (16). The tests were performed for 3 continuous days. The passive avoidance test was performed to assess short-term learning ability. Following a single training trial, time latency was measured (consolidation trial). The room in which tests were performed was kept quiet and dark. The number of correct responses (scored from 0 to 20) was recorded in the test.

Morris water maze test. The Morris water maze test was performed following a routine procedure at the Institute of Materia Medica, Chinese Academy of Medical Sciences and Peking Union Medical College. Mice were trained to swim 3 times a day for 5 consecutive days, as described previously (14). Mice were then placed into a pool of water at a desired start point and then forced to swim. The recorded latency period was considered to be the time taken for mice to locate and climb the fixed platform. If the latency time exceeded $60 \mathrm{sec}$, mice were led to the platform and $60 \mathrm{sec}$ was recorded. Mice were subsequently removed from the platform within $10 \mathrm{sec}$ following arrival and then run to the next training procedure (probe trial) (17). The data acquisition 
and analysis were completed using EthoVision XT7 (Noldus Information Technology BV, Wageningen, The Netherlands).

$H \& E$ and Nissl staining. After the aforementioned behavioral tests were performed, mice were immediately anesthetized with $400 \mathrm{mg} / \mathrm{kg}$ IP $10 \%$ chloral hydrate and then sacrificed via cardiac perfusion with saline solution, followed by ice-cold $4 \%$ paraformaldehyde in $0.1 \mathrm{M}$ phosphate buffer ( $\mathrm{pH} 7.0)$ as described previously (17). No signs of peritonitis were observed following anesthetic administration. All mice were sacrificed following behavioral tests. The brains of three randomly selected mice from each group were removed and fixed in $4 \%$ paraformaldehyde solution for $24 \mathrm{~h}$ at $4^{\circ} \mathrm{C}$. Tissues were subsequently embedded in paraffin and cut into $4 \mu \mathrm{m}$ thick sections. Samples were stained with H\&E and Nissl dyes as contrast agents via a routine staining protocol. Histopathological changes in the hippocampal CA1 region were observed using an optical microscope (magnification, $\mathrm{x} 400$ ). H\&E stained brain tissues from an additional three mice in each group were subsequently stained with hematoxylin solution for $3 \mathrm{~min}$ and NISSL staining with $1 \%$ toluidine blue staining solution for $10 \mathrm{~min}$ at room temperature. Samples were then dehydrated rapidly with $95 \%$ alcohol, cleared with xylene and mounted with the neutral resin. A high-power optical microscope (magnification, $\mathrm{x} 400$ ) was used to observe the tissue. Three randomly selected visual fields were used and the number and rate of positive cells were counted and calculated from the images.

Transmission electron microscopy (TEM). Three other mice were then selected from each group, anesthetized and sacrificed as aforementioned. The hippocampal tissues of mice were then obtained. Tissue was fixed with pre-cooled $2.5 \%$ glutaraldehyde solution at $4^{\circ} \mathrm{C}$ for over $4 \mathrm{~h}$. The hippocampal CA1 region was subsequently isolated, washed twice with $10 \mathrm{mM}$ PBS buffer and fixed in $1 \%$ osmic acid solution at $4^{\circ} \mathrm{C}$ for $1 \mathrm{~h}$. Fixed tissues were then washed twice with $10 \mathrm{mM}$ PBS buffer and treated via a routine protocol including dehydration with acetone, preservation overnight at room temperature in $70 \%$ acetone solution with saturated uranyl acetate (Amresco, LLC, Solon, OH, USA), dehydrating further with acetone and embedding using the SPURR embedding kit (TAAB Laboratories Equipment Ltd., UK). The treated tissue sections were sieved using 200-mesh copper grids, stained with uranyl acetate for $30 \mathrm{~min}$ at room temperature and further stained with lead nitrate (or lead citrate) at room temperature for 30 min. A H-600 TEM (Hitachi, Ltd., Tokyo, Japan) was used to obtain high-resolution tissue images.

Maleic dialdehyde (MDA) content and superoxide dismutase (SOD), glutathione peroxidase (GSH-PX) and acetylcholinesterase (AChE) activity. MDA content (cat. no. A003-1) and the enzyme bioactivity of SOD (cat. no. A001-3), GSH-PX (cat. no. A005) and AChE (cat. no. A024) in murine tissue were determined to assess the biochemical changes observed following drug treatment. All measurements were obtained using corresponding detection kits (Nanjing Jiancheng Bioengineering Institute) following the manufacturer's protocol.

Statistical analysis. All statistical data were analyzed using SPSS software v. 17.0 (SPSS Inc., Chicago, IL, USA) and data are presented as the mean \pm standard error of the mean. Differences between two groups were analyzed via a Student's t-test and among multiple groups via one-way analysis of variance followed by a least-significant difference test. $\mathrm{P}<0.05$ was considered to indicate a statistically significant difference.

\section{Results}

In the current study, $\mathrm{PhG}$ extracts from Monochasma savatieri Franch, including TB and SA, were assessed for their neuroprotective effects as well as their potential to prevent and treat $\mathrm{AD}$ development. Their specific signaling pathways and medical effects were also assessed. A detailed flow chart of the in vivo and in vitro experimental design is presented in Fig. 1. In addition to the biochemical and medical mechanisms utilized by TB and SA, behavioral and neuroscientific tests were performed to assess murine spatial learning and memory following $A \beta_{25-35}$ induction and subsequent treatment.

SH-SY5Y cell viability following A $\beta_{25-35}$ treatment. SH-SY5Y cells were induced with $0,5,10,20,30$ and $40 \mu \mathrm{M} \mathrm{A} \beta_{25-35}$. The viability of SH-SY5Y cells was revealed to decrease with $\mathrm{A} \beta_{25-35}(10,20,30$ and $40 \mu \mathrm{M}), \mathrm{P}<0.05$; Fig. 2), indicating marked injury to cells. To avoid an over cytotoxic effect and as SH-SY5Y cell viability was $63.4 \%, 30 \mu \mathrm{M}$ of $\mathrm{A} \beta_{25-35}$ was selected as the optimal concentration for subsequent experimentation.

Effect of TB and SA on the morphology and viability of $A \beta_{25-35}$-induced SH-SY5Y cells. The morphology of SH-SY5Y cells with or without treatment are presented in Fig. 3A. The results demonstrated that cells in the control group were tightly arranged, exhibiting round and well-stained nuclei. However, following induction via $A \beta_{25-35}$, cells exhibited marked shrinkage, with dark-blue nuclei and a reduced refractive index following $30 \mu \mathrm{M}$ of $\mathrm{A} \beta_{25-35}$, indicating a growth inhibitory effect. However, following treatment with different concentrations of TB or SA, A $\beta_{25-35}$-induced SH-SY5Y cells exhibited a marked restoration of morphology.

An MTT assay was performed to assess cell viability following treatment. Compared with the cells in the control group, those induced by $A \beta_{25-35}$ exhibited a significantly decreased cell viability $(\mathrm{P}<0.05$; Fig. $3 \mathrm{~A}$ and $\mathrm{B})$ with an increase of $\mathrm{A} \beta_{25-35}$ concentration as presented. However, cell viability increased as TB or SA treatment concentration increased, indicating that alongside the changes in cell morphology, $\mathrm{A} \beta_{25-35}$-induced SH-SY5Y cell viability was also increased in a dose-dependent manner at a TB and SA concentration range of 25-100 $\mu \mathrm{M}$ (Fig. 3A and B).

Effect of TB and SA on A $\beta_{25-35}$-induced SH-SY5Y cell oxidative stress. A DCFH-DA assay was preformed to assess the levels of oxidative stress in $\mathrm{A} \beta_{25-35}$-induced SH-SY5Y cells. As presented in Fig. 4, the mean fluorescence intensity (MFI) of intracellular ROS in A $\beta_{25-35}$-induced SH-SY5Y cells was increased compared with the control group $(\mathrm{P}<0.05)$. In contrast, the MFI value of $\mathrm{A} \beta_{25-35}$-induced SH-SY5Y cells gradually decreased with an increase of TB or SA concentration in a dose-dependent manner $(\mathrm{P}<0.05)$, indicating that treatment reduced cell ROS content. 


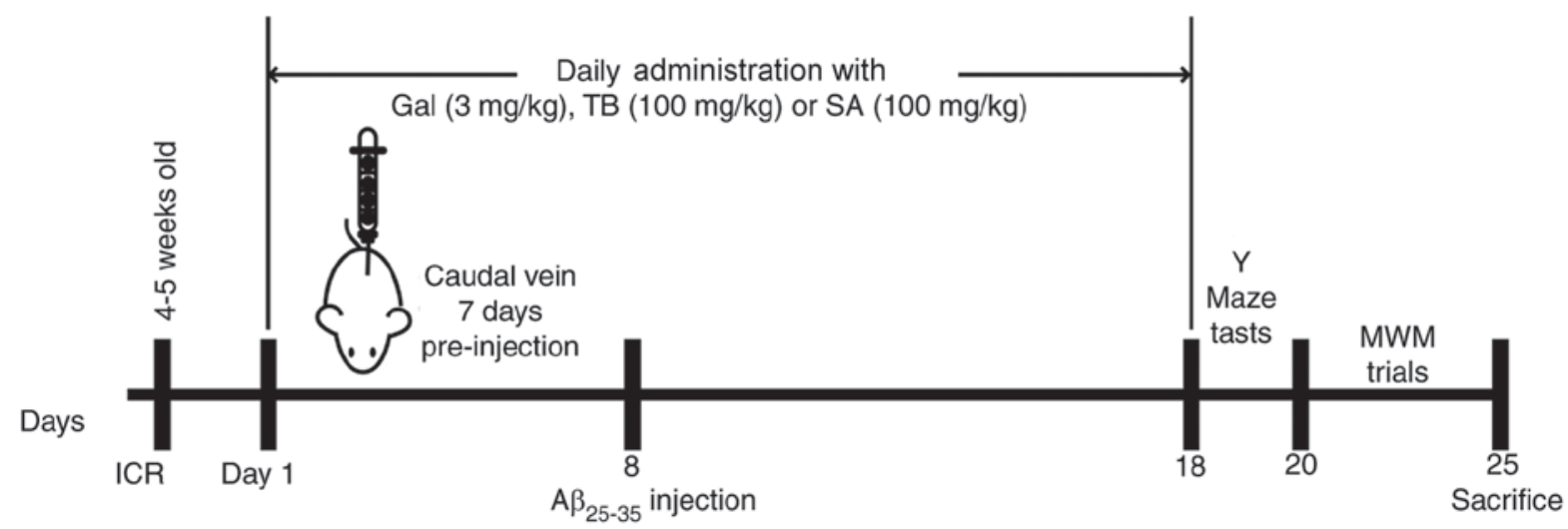

Figure 1. Flow chart of cellular and animal experiments. Gal, galantamine; TB, torenoside B; SA, savatiside A; A $\beta$, amyloid-beta; MWM, Morris water maze; ICR, Institute of Cancer Research.

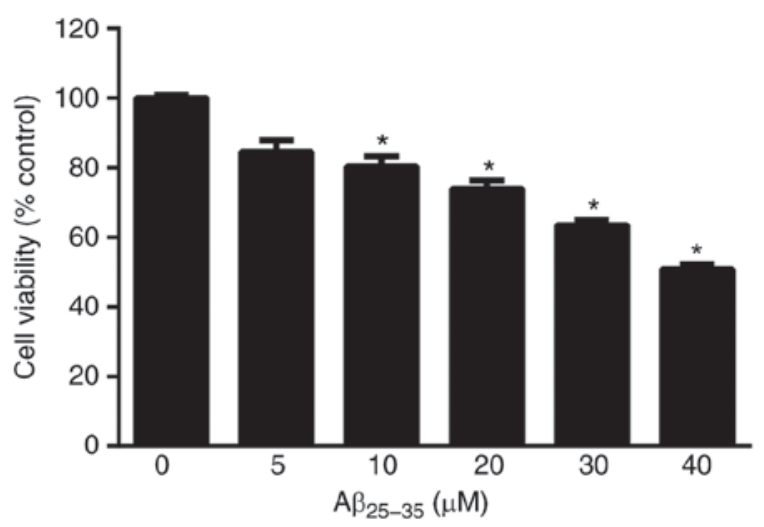

Figure 2. Effect of different concentrations of $\mathrm{A} \beta_{25-35}(0,5,10,20,30$ and $40 \mu \mathrm{M})$ on the viability of SH-SY5Y cells. " $\mathrm{P}<0.05$ vs. $0 \mu \mathrm{M}$. A $\beta$, amyloid-beta.

Furthermore, the MDA content of $A \beta_{25-35}$-induced SH-SY5Y cells was markedly elevated following TB and SA treatment, whereas the enzyme activities of SOD and GSH-PX were clearly reduced in comparison with control cells. Thus, oxidative stress parameters were decreased following treatment with increased TB and SA concentrations. These data with TB and SA treatments at the different concentrations are presented in Tables I and II.

Effect of TB and SA on the intracellular $\mathrm{Ca}^{2+}$ concentration and calnexin expression of $A \beta_{25-35}$-induced $S H$-SY5Y cells. The intracellular $\mathrm{Ca}^{2+}$ concentration of $\mathrm{A} \beta_{25-35}$-induced SH-SY5Y cells was measured using the Fluo-3AM staining method and the MFI of intracellular $\mathrm{Ca}^{2+}$ was recorded via flow cytometry. The results demonstrated that the intracellular $\mathrm{Ca}^{2+}$ concentration of $\mathrm{A} \beta_{25-35}$-induced SH-SY5Y cells decreased following TB or SA treatment in a dose-dependent manner (Fig. 5A-C). This indicates that TB and SA treatment may reduce the function of $\mathrm{Ca}^{2+}$ in cells.

The expression of Calnexin was determined following western blotting. Compared with the control group, Calnexin expression increased following $\mathrm{A} \beta_{25-35}$-induction in SH-SY5Y cells. However, TB (50-100 $\mu \mathrm{M})$ and SA $(50-100 \mu \mathrm{M})$ treatment significantly decreased the expression of Calnexin in a dose dependent manner when compared with $\mathrm{A} \beta_{25-35}$-induced SH-SY5Y cells (Fig. 5D-F).
Effect of TB and SA treatment on the learning and memory of $A \beta_{25-35}$-induced mice. The Morris water maze test was utilized to assess the learning and memory of $\mathrm{A} \beta_{25-35}$-induced mice. The results revealed that the mice induced by $\mathrm{A} \beta_{25-35}$ exhibited markedly prolonged escape latency, markedly decreased crossing numbers and significantly reduced time spent in the target quadrant in comparison with mice in the control group on the 3rd day $(\mathrm{P}<0.05$; Fig. 6A-C). However, following treatment with SA, TB or Gal, $\mathrm{A} \beta_{25-35}$-induced mice exhibited a significantly improved non-spatial relational learning and memory $(\mathrm{P}<0.05)$ compared with untreated mice, indicating that $\mathrm{SA}$ and TB served as affective treatments.

In the Y-maze test, following an $\mathrm{A} \beta_{25-35}$ injection to murine hippocampal regions, the spatial recognition memory of mice was demonstrated to be significantly reduced, as presented in Fig. 6D-E $(\mathrm{P}<0.05)$. SA and TB compounds were subsequently administered to treat injured mice. The results revealed an effective improvement on the spatial recognition memory of $\mathrm{A} \beta_{25-35}$-induced mice (all $\mathrm{P}<0.05$ ), which was consistent with the treatment by the Gal.

Effect of TB and SA on the histopathological morphology and neuronal ultrastructure of $A \beta_{25-35}$ induced murine hippocampal CAl regions. H\&E staining was performed to monitor neuronal morphology and pyramidal cells in the hippocampal CA1 region of mice. The results revealed that mice in the control group exhibited a normal neuronal morphology, with well-arranged pyramidal cells (Fig. 7). In contrast, $\mathrm{A} \beta_{25-35}$-induced mice exhibited a markedly decreased number of pyramidal cells. The cells were arranged dispersedly in a disordered manner. However, following SA or TB treatment, the number of pyramidal cells and the degree of cell edema were observed to be improved.

The neuronal structure of murine brains was determined via Nissl staining. The results revealed that the control group exhibited a complete neuron structure, with clearly visible nucleoli, lightly stained cytoplasm and a neat arrangement in the hippocampus. In contrast, the tissues of mice from the $\mathrm{A} \beta_{25-35}$ group exhibited significant cell shrinkage, irregular cell morphology, cell membrane shrinkage, pyknotic and deeply stained nuclei, loosely arranged hippocampal cells, decreased pyramidal cells and decreased Nissl bodies. Following treatment with Gal, SA and TB, the pyramidal cells and Nissl 
A

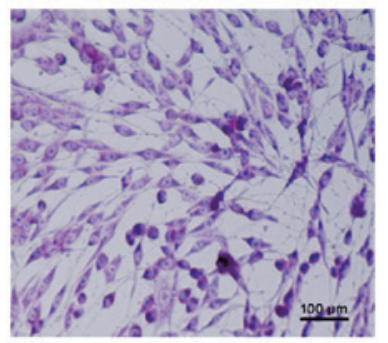

Control

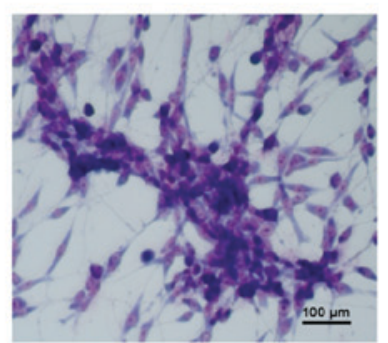

$A \beta_{25-35}$
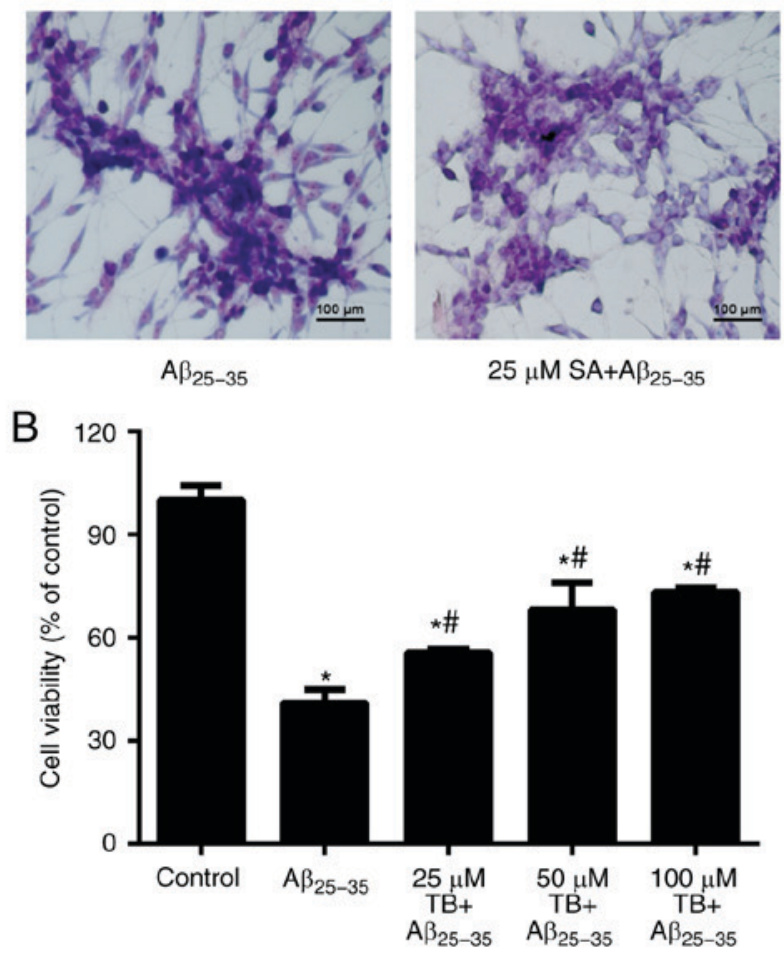

$25 \mu \mathrm{M} \mathrm{SA}+\mathrm{A} \beta_{25-35}$

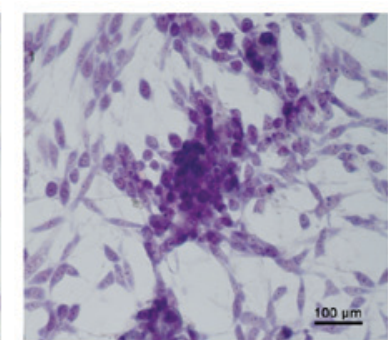

$50 \mu \mathrm{M}$ TB+A $\beta_{25-35}$

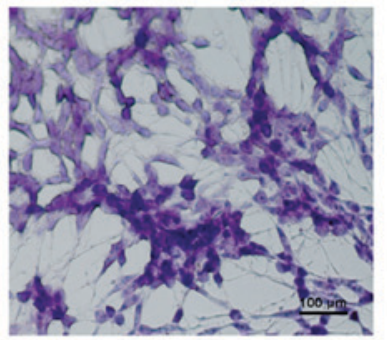

$50 \mu \mathrm{M} \mathrm{SA}+\mathrm{A} \beta_{25-35}$

C

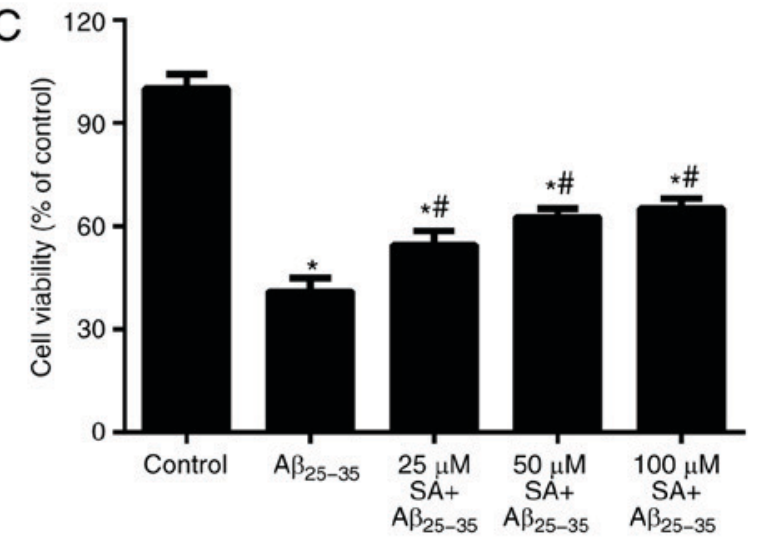

Figure 3. (A) Morphological changes of A $\beta_{25-35}$-induced TB and SA treated SH-SY5Y cells (magnification, $\mathrm{x} 400$ ). SH-SY5Y cell viability following (B) TB and (C) SA treatments at different concentrations $(25,50$ and $100 \mu \mathrm{M})$. Control, $\mathrm{A} \beta_{25-35}$ alone, TB and SA treatments were performed using the same cells cultured and subsequently imaged at the same time. Therefore, results are presented in the same panel to improve comparisons. ${ }^{*}<0.05$ vs. the control group; ${ }^{\#} \mathrm{P}<0.05$ vs. the $\mathrm{A} \beta_{25-35}$ group. $\mathrm{A} \beta$, amyloid-beta; $\mathrm{TB}$, torenoside $\mathrm{B} ; \mathrm{SA}$, savatiside $\mathrm{A}$.

bodies in the hippocampal CA1 region of $A \beta_{25-35}$-induced mice were substantially improved, demonstrating treatment efficacy (Fig. 7).

TEM imaging was utilized to assess the neuronal structures of mice. It was demonstrated that control group mice had a normal distribution of neurons, smooth membrane surfaces and round or oval shape nuclei. However, $A \beta_{25-35}$-induced mice exhibited concentrated chromatin in the nuclei of certain neurons. Following TB and SA treatment, the neuronal structures of $\mathrm{A} \beta_{25-35}$-induced mice were ameliorated and resumed to almost normal status, with only very few abnormal nuclear ultrastructures. This observation was also similar to that of the Gal+A $\beta_{25-35}$ group, indicating that TB and SA have a similar treatment effect to Gal (Fig. 7).

Effects of $T B$ and $S A$ on the oxidative stress and neuron apoptosis of hippocampal tissues in $A \beta_{25-35}$-induced mice. The content of MDA and the activity of SOD and GSH-Px from $A \beta_{25-35}$-induced and control mice were measured (Fig. 8A-D). The results revealed that the content of MDA in $\mathrm{A} \beta_{25-35}$-induced mice was significantly higher compared with the control group. Additionally, the activities of SOD and GSH-Px were significantly lower in $\mathrm{A} \beta_{25-35}$-induced mice compared with control mice, indicating the marked aggravation of hippocampal neuron apoptosis via $A \beta_{25-35}$-induction (all $\mathrm{P}<0.05$ ). Following treatment with $\mathrm{SA}$ or TB, oxidative stress in the hippocampal tissues of $A \beta_{25-35}$-induced mice was markedly alleviated, exhibiting a decrease of MDA content, an increase in SOD and GSH-Px activity and a decrease in the number of apoptotic neurons (all $\mathrm{P}<0.05)$. A similar effect was also observed in $A \beta_{25-35}$-induced mice treated with Gal, further supporting the hypothesis that SA and TB exhibit similar effects to Gal.

Effects of $T B$ and $S A$ on AchE activity and Calnexin expression in the hippocampal tissues of $A \beta_{25-35}$-induced mice. As presented in Fig. 8E, $\mathrm{A} \beta_{25-35}$ induced mice exhibited an increased AchE activity in their hippocampal tissues compared with the control group $(\mathrm{P}<0.05)$. Following treatment with TB and SA, AchE activity of the three treated groups were markedly decreased (all $\mathrm{P}<0.05)$. Furthermore, AchE activity in each of the three treatment groups was not 

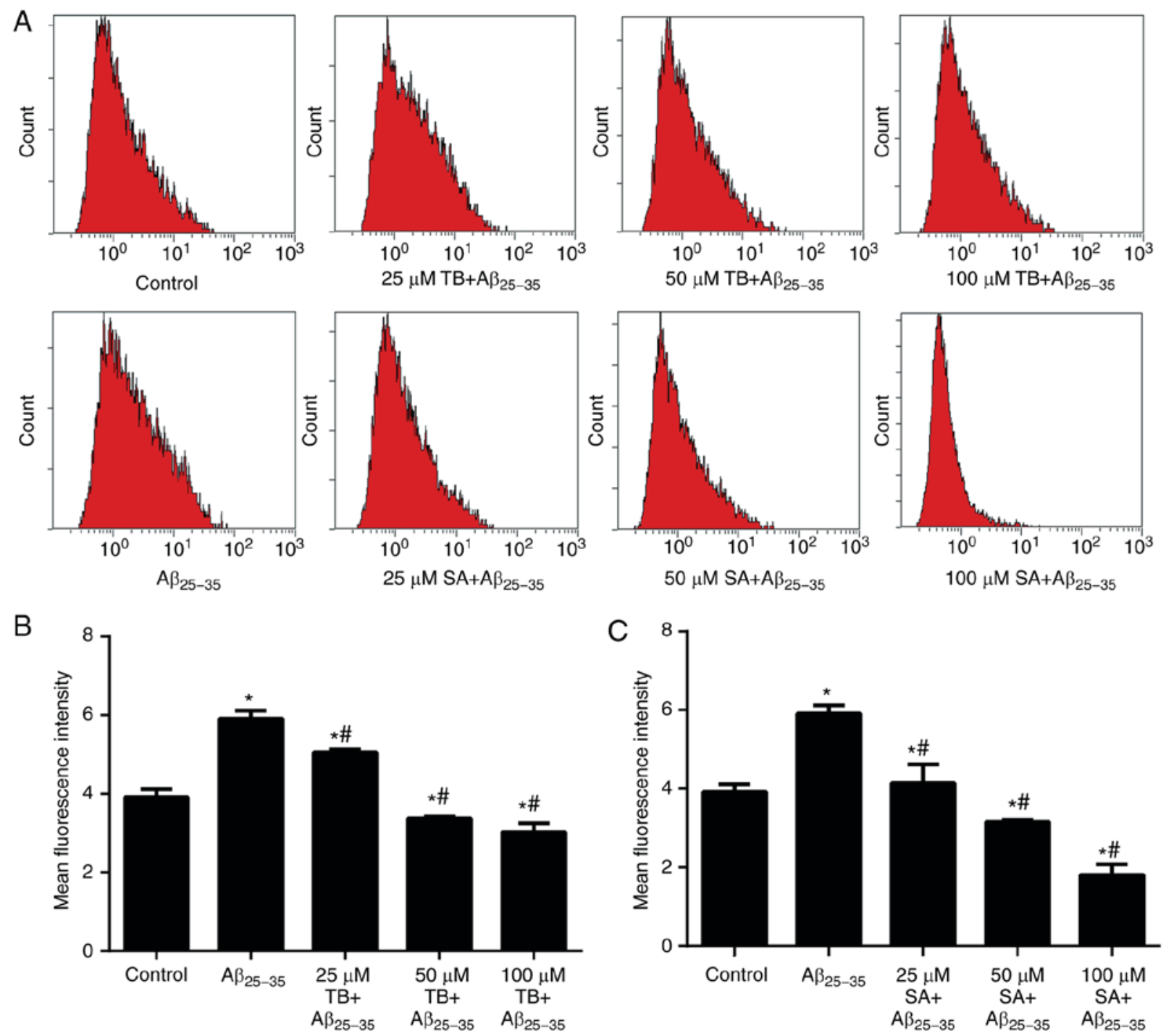

Figure 4. Effects of TB and SA treatment on reactive oxygen species production of A $\beta_{25-35}$-induced SH-SY5Y cells at different concentrations. (A) Mean fluorescence intensity was obtained using a dichlorofluorescin diacetate assay and quantified following (B) TB and (C) SA treatment. Control, A $\beta_{25-35}$ alone, TB and SA treatments were performed using the same cells cultured and subsequently imaged at the same time. Therefore, results are presented in the same panel to improve comparisons. ${ }^{*} \mathrm{P}<0.05$ vs. the control group; ${ }^{\#} \mathrm{P}<0.05$ vs. the $\mathrm{A} \beta_{25-35}$ group. TB, torenoside $\mathrm{B}$; SA, savatiside $\mathrm{A}$; $\mathrm{A} \beta$, amyloid-beta.

statistically significant when compared, indicating similar drug effects.

Western blotting was performed to detect the expression of Calnexin in the hippocampus of mice, the results of which are presented in Fig. 8F and G. The results demonstrated that Calnexin expression in $A \beta_{25-35}$ induced mice was significantly higher than that of the control group $(\mathrm{P}<0.05)$. Furthermore, following treatment with TB, SA and GAL, the expression of Calnexin in $A \beta_{25-35}$-induced mice markedly decreased $(\mathrm{P}<0.05)$, indicating a significant and similar treatment efficacy of SA, TB and GAL.

\section{Discussion}

$\mathrm{A} \beta$ fragments are derived from a family of peptides that are closely associated with the pathogenesis and development of $\mathrm{AD}(13,18)$. The $\mathrm{A} \beta_{25-35}$ fragment in particular, exhibits a high cytotoxicity, rapid aggregation and an enhanced neurotoxicity (13). The toxic effect of $A \beta_{25-35}$ on nervous cells has been well document via in vitro and in vivo experiments $(19,20)$. In the current study, $A \beta_{25-35}$ was used to induce SH-SY5Y cells at different concentrations. The results revealed a marked decrease in cell viability with increased $\mathrm{A} \beta_{25-35}$ concentrations, which is consistent with the results of previous studies $(21,22)$. To avoid adverse effects following induction, $30 \mu \mathrm{M}$ of $\mathrm{A} \beta_{25-35}$ (with a cell viability of $63.4 \%$ ) was selected for subsequent cell-based in-vitro experiments.

In accordance with typical protocols for drug treatment, cells and mice were first induced with $A \beta_{25-35}$ and then treated with drugs to determine their effect on cell injury. The current study assessed the protective role of PhGs in AD. Thus, cells and mice were treated with $\mathrm{PhGs}$ following induction with $\mathrm{A} \beta_{25-35}$, which is a procedure that has been utilized in a previous publication (23).

$\mathrm{A} \beta_{25-35}$ is closely associated with the pathogenesis and progression of many neurodegenerative diseases, including Parkinson's disease, amyotrophic lateral sclerosis and AD (24), via a modulating oxidative stress pathway. Thus, 
Table I. Effect of TB concentration on MDA, SOD and GSH-Px levels in A $\beta_{25-35}$-induced SH-SY5Y cells.

\begin{tabular}{lccr}
\hline Group & MDA $(\mathrm{mmol} / \mathrm{mg})$ & SOD $(\mathrm{U} / \mathrm{mg})$ & GSH-Px $(\mathrm{U} / \mathrm{mg})$ \\
\hline Control & $0.94 \pm 0.10$ & $44.08 \pm 0.95$ & $56.53 \pm 2.61$ \\
$\mathrm{~A} \beta_{25-35}$ & $2.23 \pm 0.17^{\mathrm{a}}$ & $11.67 \pm 0.35^{\mathrm{b}}$ & $21.12 \pm 0.28^{\mathrm{b}}$ \\
$25 \mu \mathrm{MB}+\mathrm{A} \beta_{25-35}$ & $1.57 \pm 0.41^{\mathrm{d}}$ & $19.75 \pm 3.39$ & $28.16 \pm 1.73$ \\
$50 \mu \mathrm{M} \mathrm{TB}+\mathrm{A} \beta_{25-35}$ & $1.25 \pm 0.04^{\mathrm{d}}$ & $30.48 \pm 0.40^{\mathrm{d}}$ & $32.88 \pm 3.29$ \\
$100 \mu \mathrm{M} \mathrm{TB}+\mathrm{A} \beta_{25-35}$ & $1.07 \pm 0.60^{\mathrm{d}}$ & $32.12 \pm 2.15^{\mathrm{c}}$ & $37.95 \pm 1.29^{\mathrm{d}}$ \\
\hline
\end{tabular}

${ }^{\mathrm{a}} \mathrm{P}<0.05$ and ${ }^{\mathrm{b}} \mathrm{P}<0.01$ vs. the control group; ${ }^{\mathrm{C}} \mathrm{P}<0.05$ and ${ }^{\mathrm{d}} \mathrm{P}<0.01$ vs. the $\mathrm{A} \beta_{25-35}$ group. Data are presented as mean \pm standard error of the mean. $\mathrm{TB}$, torenoside $\mathrm{B}$; MDA, maleic dialdehyde; SOD, superoxide dismutase; A $\beta$, amyloid-beta; GSH-PX, glutathione peroxidase.

Table II. Effect of SA concentration on MDA, SOD and GSH-PX levels in A $\beta_{25-35}$-induced SH-SY5Y cells .

\begin{tabular}{lccc}
\hline Group & MDA $(\mathrm{mmol} / \mathrm{mg})$ & SOD $(\mathrm{U} / \mathrm{mg})$ & GSH-Px $(\mathrm{U} / \mathrm{mg})$ \\
\hline Control & $1.14 \pm 0.60$ & $37.22 \pm 0.4$ & $62.00 \pm 0.03$ \\
$\mathrm{~A} \beta_{25-35}$ & $3.05 \pm 0.63^{\mathrm{a}}$ & $9.25 \pm 0.15^{\mathrm{a}}$ & $18.77 \pm 0.02^{\mathrm{b}}$ \\
$25 \mu \mathrm{M} \mathrm{SA}+\mathrm{A} \beta_{25-35}$ & $2.10 \pm 0.12^{\mathrm{c}}$ & $22.96 \pm 0.11^{\mathrm{c}}$ & $25.85 \pm 0.03^{\mathrm{c}}$ \\
$50 \mu \mathrm{M} \mathrm{SA}+\mathrm{A} \beta_{25-35}$ & $1.54 \pm 0.14^{\mathrm{c}}$ & $27.45 \pm 0.07^{\mathrm{c}}$ & $33.02 \pm 0.01^{\mathrm{c}}$ \\
$100 \mu \mathrm{M} \mathrm{SA}+\mathrm{A} \beta_{25-35}$ & $1.20 \pm 0.01^{\mathrm{d}}$ & $29.96 \pm 0.06^{\mathrm{d}}$ & $35.27 \pm 0.03^{\mathrm{d}}$ \\
\hline
\end{tabular}

${ }^{a} \mathrm{P}<0.05$ and ${ }^{\mathrm{b}} \mathrm{P}<0.01$ vs. the control group; ${ }^{\mathrm{P}}<0.05$ and ${ }^{\mathrm{d}} \mathrm{P}<0.01$ vs. the $\mathrm{A} \beta_{25-35}$ group. Data are presented as the mean \pm standard error of the mean. SA, savatiside A; MDA, maleic dialdehyde; SOD, superoxide dismutase; A $\beta$, amyloid-beta; GSH-PX, glutathione peroxidase.
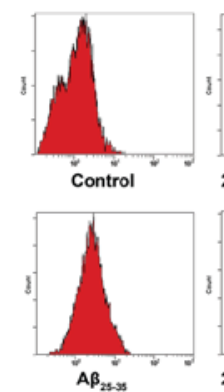

$25 \mu \mathrm{MTB}+A \beta_{25,15}$

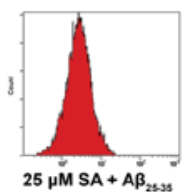

$25 \mu \mathrm{MSA}+A \beta_{25,3}=50 \mu \mathrm{MSA}+A \beta_{25,35}$
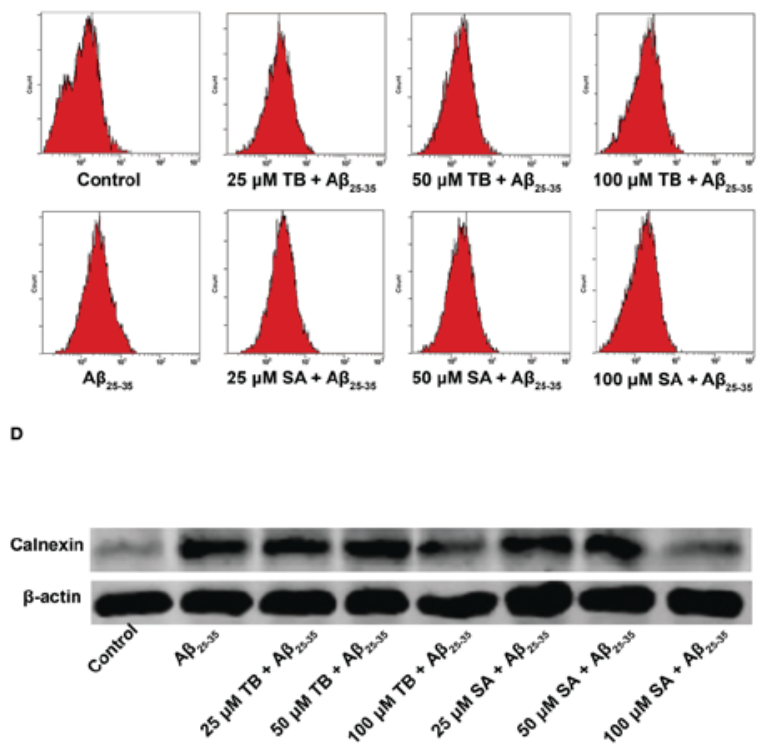
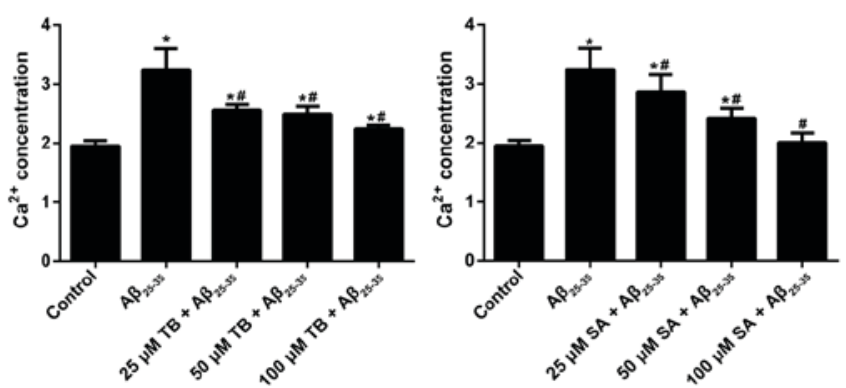

E

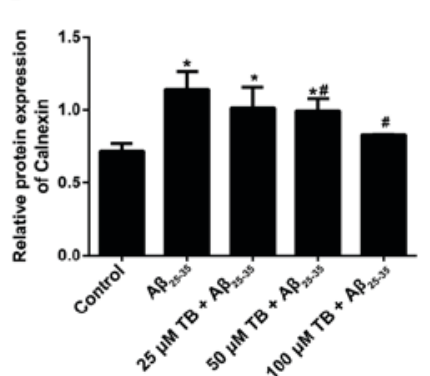

F

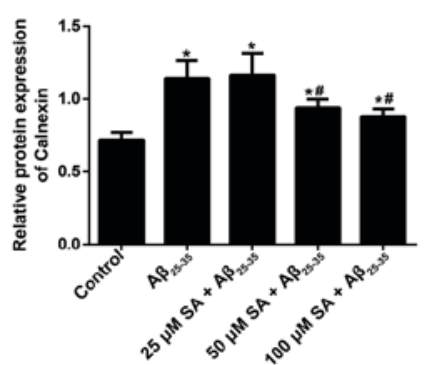

Figure 5. Effect of TB or SA treatment on the intracellular $\mathrm{Ca}^{2+}$ concentration of $\mathrm{A} \beta_{25-35}$-induced SH-SY5Y cells at different concentrations (25, 50 and $\left.100 \mu \mathrm{M}\right)$. (A) Measurements were obtained using the Fluo-3AM staining method and quantified following (B) TB and (C) SA treatments. (D) Western blotting was performed to assess the effect of (E) TB or (F) SA treatment on Calnexin expression in A $\beta_{25-35}$-induced SH-SY5Y cells at different concentrations $(25,50$ and $100 \mu \mathrm{M})$. Control, $\mathrm{A} \beta_{25-35}$ alone, TB and SA treatments were performed using the same cells cultured and subsequently imaged at the same time. Therefore, results are presented in the same panel to improve comparisons. ${ }^{*} \mathrm{P}<0.05$ vs. the control group; ${ }^{\#} \mathrm{P}<0.05$ vs. the $\mathrm{A} \beta_{25-35}$ group. TB, torenoside $\mathrm{B}$; SA, savatiside A; A $\beta$, amyloid-beta.

as a product of normal aerobic metabolism, ROS is considered to maintain a dynamic balance of its production and clearance under normal circumstances (25). However, an impaired balance of ROS or antioxidant may contribute to the 

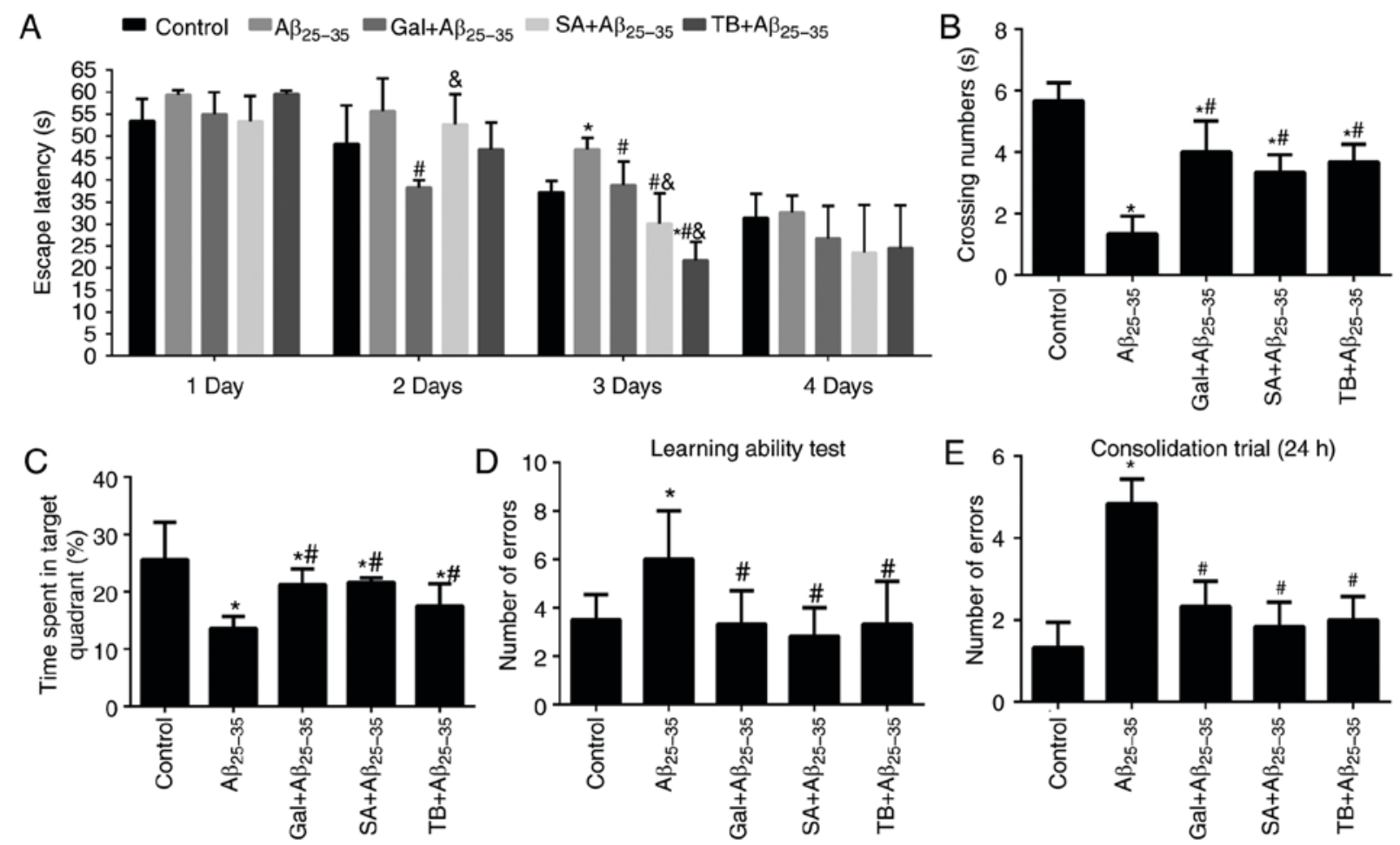

Figure 6. Effect of $\mathrm{TB}$ or SA on the learning and memory of $\mathrm{A} \beta_{25-35}$-induced mice. (A) Escape latency, (B) crossing number and (C) time spent in a target quadrant were assessed via a Morris water maze test. (D) A learning ability test and (E) consolidation trial was performed during a Y-maze test in $\mathrm{A} \beta_{25-35}$-induced mice. ${ }^{*} \mathrm{P}<0.05$ vs. the control group; ${ }^{\#} \mathrm{P}<0.05$ vs. the $\mathrm{A} \beta_{25-35}$ group; ${ }^{\circledR} \mathrm{P}<0.05$ vs. the $\mathrm{Gal}+\mathrm{A} \beta_{25-35}$ group. TB, torenoside $\mathrm{B} ; \mathrm{SA}$, savatiside $\mathrm{A}$; A $\beta$, amyloid-beta.
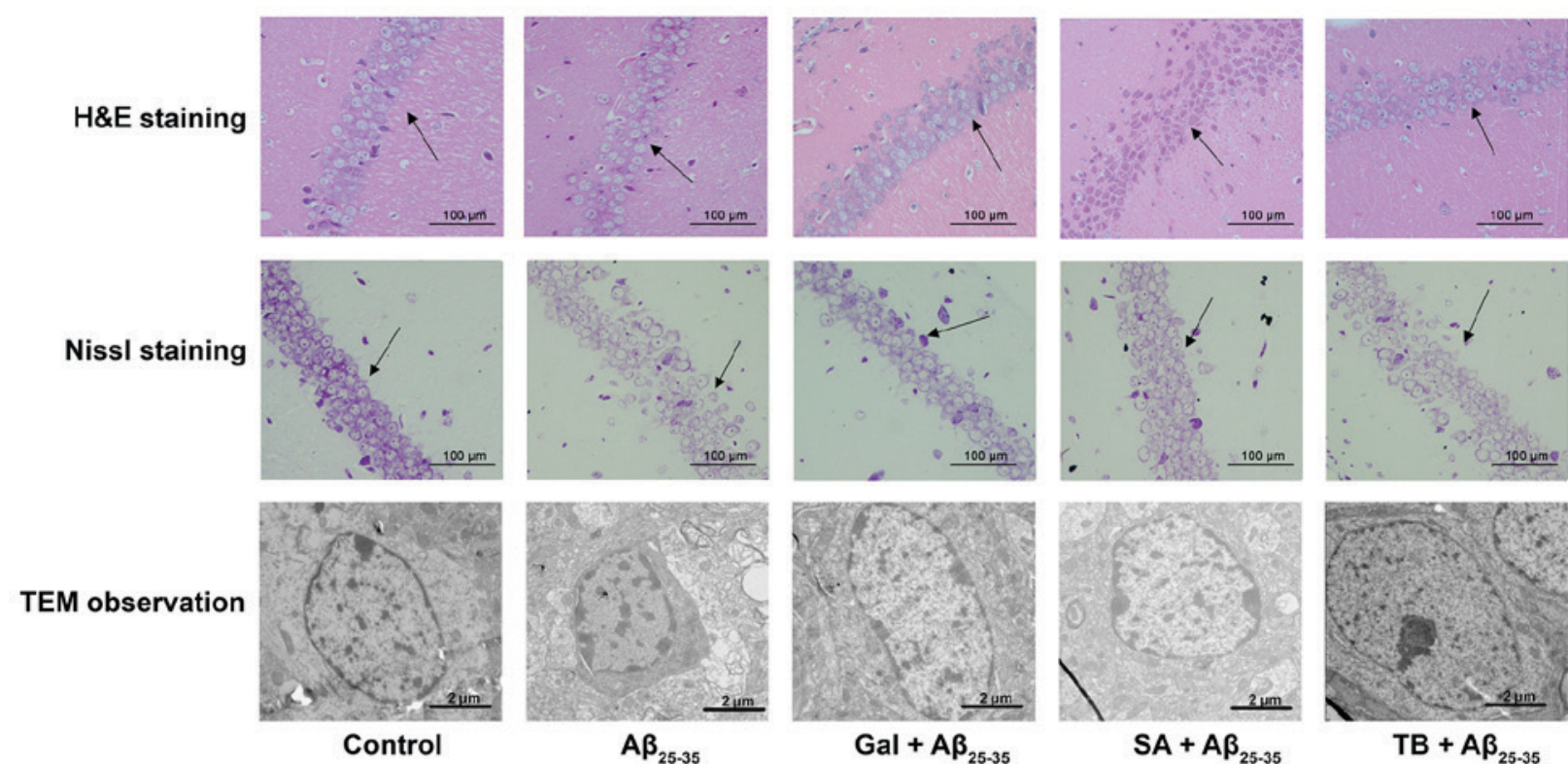

$\mathrm{Gal}+\mathbf{A} \beta_{25.35}$
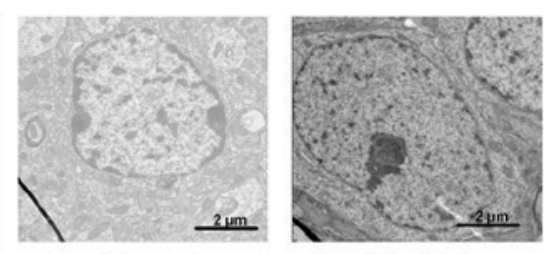

$T B+A \beta_{25.35}$

Figure 7. Effect of TB and SA on the histopathological morphology (determined via H\&E staining and Nissl staining) and the neuronal ultrastructure (determined via TEM; caliper $=2.0 \mu \mathrm{m}$ ) of the hippocampal CA1 region of $\mathrm{A} \beta_{25-35}$-induced mice. Black arrows indicate neuronal structures and arranged cells in the hippocampus; TB, torenoside B; SA, savatiside A; H\&E, hematoxylin and eosin; TEM, transmission electron microscopy; A $\beta$, amyloid-beta.

accumulation of ROS, resulting in oxidative stress-induced cell injury (26). MDA, a byproduct of free radical lipid attack, is recognized as a biomarker of lipid peroxidation and oxidative stress $(27,28)$. In addition, certain enzymes, including catalase, GSH-Px and SOD, may prevent ROS induced cell injury via detoxification (29).
The current study determined the content of MDA and the enzyme activities of GSH-Px and SOD to determine oxidative stress-induced cell injury following $A \beta_{25-35}$ treatment, and the treatment efficacy of antioxidants in the PhGs extracted from Monochasma savatieri Franch. PhGs are naturally distributed in dicotyledonous plants and are usually comprised of 

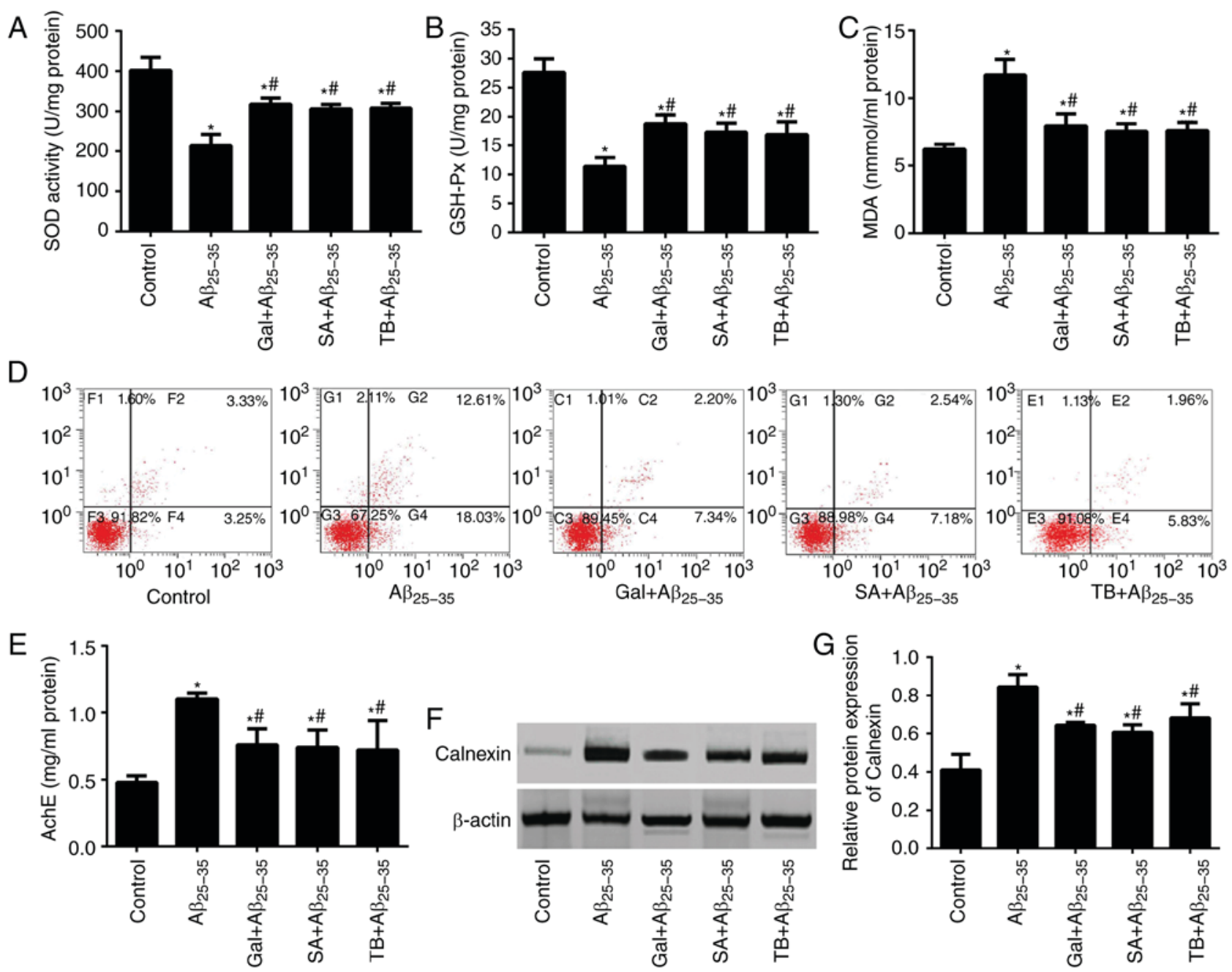

Figure 8. Effect of TB and SA on oxidative stress, apoptosis, AchE activity and Calnexin expression of hippocampal tissues in A $\beta_{25-35}$-induced mice. Activities of (A) SOD, (B) GSH-Px and (C) MDA content. (D) Hippocampal neuron apoptosis was assessed in mice using an Annexin V-EGFP/PI double staining method (E) AchE activity in the hippocampal tissues of mice. The expression of Calnexin in the mice determined via (F) western blotting and subsequent (G) quantification. " $\mathrm{P}<0.05$ vs. the control group; ${ }^{\#} \mathrm{P}<0.05$ vs. the $\mathrm{A} \beta_{25-35}$ group. $\mathrm{TB}$, torenoside $\mathrm{B} ; \mathrm{SA}$, savatiside $\mathrm{A}$; AchE, acetylcholinesterase; $\mathrm{A} \beta$, amyloid-beta; SOD, superoxide dismutase; GSH-PX, glutathione peroxidase; MDA, maleic dialdehyde.

a $\beta$-glucosamine core with hydroxyl and methoxy subunits substituting phenyl or cinnamoyl substituent groups via ester or glycosidic linkages $(30,31)$. Certain PhGs have also been demonstrated to exert a significant anti-oxidative stress effect (32). For instance, acteoside, extracted from Verbascum sinuatum, protects SH-SY5Y cells against A $\beta$-induced cell injury by modulating ROS generation and apoptosis via a signal pathway comprising the B cell lymphoma-2 family, cytochrome-c and caspase-3 (33). Furthermore, Echinacoside, isolated from Tibetan herb Lagotis brevituba Maxim and Cistanche tubules, is considered to exert a neuroprotective role in $\mathrm{H}_{2} \mathrm{O}_{2}$-injured PC12 cells by regulating the mitochondrial apoptotic pathway (34). TB and SA, as two types of PhG extracted from Monochasma savatieri Franch, were utilized in the current study to assess their neuroprotective efficacy in in vitro and in vivo experiments.

SH-SY5Y cell morphology exhibited a large change following $A \beta_{25-35}$ induction, but returned to a relatively normal status following treatment with TB and SA at a high dose. Meanwhile, a different morphology and cell viability was observed following TB or SA treatment when compared with
$\mathrm{A} \beta_{25-35}$-induced cells. This may be due to different solubility of the two compounds. The morphological method provides an observation on the change of cell shape following treatment and is only used as a semi-qualitative method, whereas MTT assay is quantitative. The data obtained from each method exhibits similar trends and supports the conclusion that TB and SA may serve as efficient treatments of AD.

$\mathrm{A} \beta_{25-35}$ induced SH-SY5Y cells upregulated intracellular ROS content and MDA, but downregulated SOD and GSH-Px. These results indicate that $A \beta_{25-35}$-induced oxidative stress may constitute a cause for the cell injury observed in $\mathrm{AD}$ development. This may be due to the binding of $\mathrm{A} \beta$ to the advanced glycation end product cell membrane receptor, activating nuclear factor (NF)- $\mathrm{kB}$ and subsequently generating ROS (35). An in vitro experiment was then performed in the present study, in which $A \beta_{25-35}$-induced cells were treated with TB and SA extracts. Gal was also utilized in certain tests as the positive control. The results revealed that TB and SA treatment significantly decreased ROS and MDA content, and increased SOD and GSH-Px in a dose-dependent manner. A previous study also determined that SA exerts a protective 
effect against myocardial ischemia injury (7). The current study demonstrated that SA and TB compounds may function as antioxidants and thus prevent AD by eliminating ROS or preventing its production, and by slowing down or completely inhibiting degenerative changes in nerve cells. The effect of SA and TB may be a result of phenolic hydroxyl groups present in their chemical structure that may lead to anti-oxidative activities, thus exhibiting free radical removal and oxidative cracking (36).

To further verify the anti-oxidative and anti-apoptosis properties of TB and SA, the extracts were administered $\mathrm{A} \beta_{25-35}$-induced mice. It is considered that the majority of people with AD are older ( $\geq 65$ years) and as such, the age of experimental animals is a critical variable in experimental research (37). The current study assessed the protective role of PhGs in AD. It has been revealed that $\mathrm{A} \beta$ can be detected in the mice at 2-3 weeks old and remains at a relatively low level at $4-5$ weeks old $(38,39)$. Thus, to reduce the natural $A \beta$ interference in the brains of mice, the current study utilized 4-5 weeks old mice to construct AD models.

According to a previous study, A $\beta$ binds to N-methyl$\mathrm{D}$-aspartate receptors, regulating calcium channels and increasing the number of open channels on the cell surface (40). This phenomenon may increase the influx of extracellular calcium, triggering the release of mitochondrial calcium and resulting in the destabilization of calcium homeostasis and the increased production of ROS (41). However, PhG compounds serve an essential role in the maintenance of calcium homeostasis. For instance, echinacoside induces pulmonary artery vasorelaxation in mice by increasing the number of open NO-cGMP-PKG-BKCa channels and decreasing intracellular $\mathrm{Ca}^{2+}$ levels (42). In addition, acteoside inhibits the invasive and migrating capabilities of phorbol-12-myristate-13-acetate-induced human fibrosarcoma cells by regulating the $\mathrm{Ca}^{2+}$-dependent calmodulin-dependent protein kinase/extracellular regulated kinase and Jun amino-terminal kinase/NF- $\kappa \mathrm{B}$ pathways (43). The results of the current study reveal that TB and SA treatment inhibited the concentration of intracellular $\mathrm{Ca}^{2+}$ and the expression of Calnexin in $A \beta_{25-35}$-induced cells. This observation was also supported by the results of in-vivo experiments. Thus, it is suggested that TB and SA compounds may downregulate the expression of proteins that are associated with the Calnexin transduction pathway, alleviating the destabilizing state of calcium homeostasis in neurons, and exerting therapeutic effects in AD.

As determined in the present study, SA $(100 \mathrm{mg} / \mathrm{kg} / \mathrm{d})$ and TB $(100 \mathrm{mg} / \mathrm{kg} / \mathrm{d})$ treatment effectively improves the spatial, non-spatial learning and memory capabilities of $A \beta_{25-35}$-injured mice. Furthermore, SA and TB treatment was revealed to ameliorate the morphology and structure of pyramidal cells in the hippocampal CA1 region, increase the number of Nissl bodies and reduce AchE activity in $\mathrm{A} \beta_{25-35}$-injured mice. As a hydrolase of the central nervous system, AchE serves a key role in hydrolyzing acetylcholine (ACh) and terminating the conduction of nerve impulses (44). The results of the current study demonstrated that SA and TB compounds function as efficient AChE inhibitors, indicating their potential treatment efficiency.

As a drug to treat mild to moderate confusion in dementia associated $\mathrm{AD}, \mathrm{Gal}$ is not curative, but may improve memory, awareness and the ability to perform daily tasks (45). However, it also exerts side effects including nausea, vomiting, stomach pain, diarrhea, dizziness, loss of appetite, weight loss and tiredness (46). In the current study, Gal was utilized as a positive control in certain tests, the results of which were compared with the efficacy of TB and SA treatment. Of significance, the results revealed that TB and SA exhibit a similar effect to Gal in certain experiments, indicating a high treatment efficacy of TB and SA. However, the current study did not compare the side effects of TB and SA to those of Gal. Further study is required to assess the pharmacokinetics and pharmacodynamics of SA and TB compounds, as well as their bioavailability.

In the current study, TB and SA compounds exhibited potential therapeutic effects in the treatment of AD. TB and SA treatments were revealed to enhance the enzyme activity of SOD and GSH-Px, reduce the content of ROS and MDA, and downregulate intracellular $\mathrm{Ca}^{2+}$ concentrations and Calnexin expression in $\mathrm{A} \beta_{25-35}$-induced SH-SY5Y cells. In addition, TB or SA treatment administered to $A \beta_{25-35}$-induced mice effectively improved their learning capability and memory, alleviated their oxidative stress in the hippocampal tissues, significantly decreased the expression of Calnexin and decreased hippocampal neuron apoptosis. The results revealed that $\mathrm{SA}$ and $\mathrm{TB}$ compounds may have a potential for use as therapeutic drugs to treat AD. However, although the formation of plaques or tangles in mice may verify the success of animal model construction, the staining and observation of plaque and tangle formation were neglected in the experimental design of the current study to reduce possible interference from multiple staining protocols and to avoid the complexity and subsequent discussion of experimental results. This matter should therefore be addressed in future studies.

\section{Acknowledgements}

Not applicable.

\section{Funding}

The current study was funded by Jiangsu Science and Technology Support Program-Social Development Project (grant no. BE2013631).

\section{Availability of data and materials}

All data generated or analyzed during this study are included in this published article.

\section{Authors' contributions}

SJ, SL, XZ, NK, KC, YZ, PP and JF performed the experiments, analyzed the data and prepared the manuscript. YL, QX and SY conceived and designed the current study.

\section{Ethics approval and consent to participate}

The current study was approved by the Ethics Committee of Soochow University (approval no. 201505895).

\section{Patient consent for publication}

Not applicable. 


\section{Competing interests}

The authors declare that they have no competing interests.

\section{References}

1. Feldman HH and Estabrooks CA: The Canadian dementia challenge: Ensuring optimal care and services for those at risk or with dementia throughout the country. Can J Public Health 108: e95-e97, 2017.

2. Josephs K, Whitwell JL, Weigand S, Murray ME, Tosakulwong N, Liesinger A, Petrucelli L, Senjem M Knopman DS, Boeve BF, et al: Tdp-43 amplifies memory loss and hippocampa atrophy in Alzheimer's disease. Alzheimers Dementia 10: P279-P280, 2014.

3. Zhang DF, Li J, Wu H, Cui Y, Bi R, Zhou HJ, Wang HZ, Zhang C, Wang D; Alzheimer's Disease Neuroimaging Initiative (ADNI), et al: CFH Variants affect structural and functional brain changes and genetic risk of Alzheimer's disease. Neuropsychopharmacology 41: 1034-1045, 2016.

4. Atwood CS, Martins RN, Smith MA and Perry G: Senile plaque composition and posttranslational modification of amyloid-beta peptide and associated proteins. Peptides 23: 1343-1350, 2002.

5. Kalra J and Khan A: Reducing Abeta load and tau phosphorylation: Emerging perspective for treating Alzheimer's disease. Eur J Pharmacol 764: 571-581, 2015.

6. Li M, Shi MF, Liu YL, Xu QM and Yang SL: Phenylethanoid glycosides from Monochasma savatieri and their anticomplement activity through the classical pathway. Planta Med 78: 1381-1386, 2012.

7. Shi M, He W, Liu Y, Li X, Yang S and Xu Q: Protective effect of total phenylethanoid glycosides from Monochasma savatieri Franch on myocardial ischemia injury. Phytomedicine 20: 1251-1255, 2013

8. Liu YL, He WJ, Mo L, Shi MF, Zhu YY, Pan S, Li XR, Xu QM and Yang SL: Antimicrobial, anti-inflammatory activities and toxicology of phenylethanoid glycosides from Monochasma savatieri Franch. ex Maxim. J Ethnopharmacol 149: 431-437, 2013.

9. Hu XP, Shao MM, Song X, Wu XL, Qi L, Zheng K, Fan L, Liao CH, Li CY, He J, et al: Anti-influenza virus effects of crude phenylethanoid glycosides isolated from ligustrum purpurascens via inducing endogenous interferon- $\gamma$. J Ethnopharmacol 179: 128-136, 2016

10. Yang J, Ju B, Yan Y, Xu H, Wu S, Zhu D, Cao D and Hu J: Neuroprotective effects of phenylethanoid glycosides in an in vitro model of Alzheimer's disease. Exp Ther Med 13: 2423-2428, 2017.

11. Shao SY, Feng ZM, Yang YN, Jiang JS and Zhang PC: Forsythenethosides A and B: Two new phenylethanoid glycosides with a 15-membered ring from Forsythia suspensa. Org Biomol Chem 15: 7034-7039, 2017.

12. Roura E, Andrés-Lacueva C, Estruch R and LamuelaRaventós RM: Total polyphenol intake estimated by a modified Folin-Ciocalteu assay of urine. Clin Chem 52: 749-752, 2006.

13. Kowall NW, McKee AC, Yankner BA and Beal MF: In vivo neurotoxicity of beta-amyloid [beta(1-40)] and the beta(25-35) fragment. Neurobiol Aging 13: 537-542, 1992.

14. Liu YM, Li ZY, Hu H, Xu SP, Chang Q, Liao YH, Pan RL and Liu XM: Tenuifolin, a secondary saponin from hydrolysates of polygalasaponins, counteracts the neurotoxicity induced by A $325-35$ peptides in vitro and in vivo. Pharmacol Biochem Behav 128: 14-22, 2015.

15. Guo DK, Zhu Y, Sun HY, Xu XY, Zhang S, Hao ZB, Wang GH, $\mathrm{Mu} \mathrm{CC}$ and Ren H: Pharmacological activation of REV-ERBo represses LPS-induced microglial activation through the NF- $\kappa \mathrm{B}$ pathway. Acta Pharmacol Sin 40: 26-34, 2019.

16. Ma MX, Chen YM, He J, Zeng T and Wang JH: Effects of morphine and its withdrawal on Y-maze spatial recognition memory in mice. Neuroscience 147: 1059-1065, 2007.

17. Mokhtari Z, Baluchnejadmojarad T, Nikbakht F, Mansouri M and Roghani M: Riluzole ameliorates learning and memory deficits in A 325 -35-induced rat model of Alzheimer's disease and is independent of cholinoceptor activation. Biomed Pharmacother 87: 135-144, 2017.

18. Lai W, Wu J, Zou X, Xie J, Zhang L, Zhao X, Zhao M, Wang Q and Ji J: Secretome analyses of A $\beta(1-42)$ stimulated hippocampal astrocytes reveal that CXCL10 is involved in astrocyte migration. J Proteome Res 12: 832-843, 2013.
19. Gerber H, Späth PJ, Perret BA and Burckhardt JJ: Laboratory workshop on the characterization of anti-platelet antibodies in immune thrombocytopenic purpura. Blut 59: 61-66, 1989.

20. Zhi WH, Zeng YY, Lu ZH, Qu WJ, Chen WX, Chen L and Chen L: Simvastatin exerts antiamnesic effect in A $\beta 25-35$-injected mice. CNS Neurosci Ther 20: 218-226, 2014.

21. Wang K, Zhu L, Zhu X, Zhang K, Huang B, Zhang J, Zhang Y, Zhu L, Zhou B and Zhou: Protective effect of paeoniflorin on A $325-35$-induced SH-SY5Y cell injury by preventing mitochondrial dysfunction. Cell Mol Neurobiol 34: 227-234, 2014.

22. Wei H, Gao Z, Zheng L, Zhang C, Liu Z, Yang Y, Teng H, Hou L, Yin Y and Zou X: Protective effects of fucoidan on A $\beta 25-35$ and d-Gal-induced neurotoxicity in PC12 cells and d-Gal-induced cognitive dysfunction in mice. Mar Drugs 15: pii: E77, 2017.

23. Hashimoto M, Katakura M, Hossain S, Rahman A, Shimada T and Shido O: Docosahexaenoic acid withstands the A $\beta(25-35)$-induced neurotoxicity in SH-SY5Y cells. J Nutr Biochem 22: 22-29, 2011

24. Ganguly G, Chakrabarti S, Chatterjee U and Saso L: Proteinopathy, oxidative stress and mitochondrial dysfunction: Cross talk in Alzheimer's disease and Parkinson's disease. Drug Des Devel Ther 11: 797-810, 2017.

25. Marchi S, Giorgi C, Suski JM, Agnoletto C, Bononi A, Bonora M, De Marchi E, Missiroli S, Patergnani S, Poletti F, et al: Mitochondria-ros crosstalk in the control of cell death and aging. J Signal Transduct 2012: 329635, 2012.

26. Calingasan NY, Chen J, Kiaei M and Beal MF: Beta-amyloid 42 accumulation in the lumbar spinal cord motor neurons of amyotrophic lateral sclerosis patients. Neurobiol Dis 19: 340-347, 2005.

27. Qian X, Cao H, Ma Q, Wang Q, He W, Qin P, Ji B, Yuan K, Yang F, Liu $X$, et al: Allopregnanolone attenuates A $\beta 25-35$-induced neurotoxicity in PC12 cells by reducing oxidative stress. Int J Clin Exp Med 8: 13610-13615, 2015.

28. Gomes P, Simão S, Silva E, Pinto V, Amaral JS, Afonso J, Serrão MP, Pinho MJ and Soares-da-Silva P: Aging increases oxidative stress and renal expression of oxidant and antioxidant enzymes that are associated with an increased trend in systolic blood pressure. Oxid Med Cell Longev 2: 138-145, 2009.

29. Buddi R, Lin B, Atilano SR, Zorapapel NC, Kenney MC and Brown DJ: Evidence of oxidative stress in human corneal diseases. J Histochem Cytochem 50: 341-351, 2002.

30. Si CL, Shen T, Jiang YY, Wu L, Yu GJ, Ren XD, Xu GH and $\mathrm{Hu}$ WC: Antioxidant properties and neuroprotective effects of isocampneoside II on hydrogen peroxide-induced oxidative injury in PC12 cells. Food Chem Toxicol 59: 145-152, 2013.

31. Çalis İ: Biodiversity of Phenylethanoid Glycosides. Biodiversity, pp.137-149, 2002

32. Yu P, Hu C, Meehan EJ and Chen L: X-ray crystal structure and antioxidant activity of salidroside, a phenylethanoid glycoside. Chem Biodivers 4: 508-513, 2007.

33. Wang H, Xu Y, Yan J, Zhao X, Sun X, Zhang Y, Guo J and Zhu C: Acteoside protects human neuroblastoma SH-SY5Y cells against beta-amyloid-induced cell injury. Brain Res 1283: 139-147, 2009.

34. Kuang R, Sun Y, Yuan W, Lei L and Zheng X: Protective effects of echinacoside, one of the phenylethanoid glycosides, on $\mathrm{H}(2) \mathrm{O}(2)$-induced cytotoxicity in PC12 cells. Planta Med 75: 1499-1504, 2009.

35. Hsieh $\mathrm{HM}, \mathrm{Wu} \mathrm{WM}$ and $\mathrm{Hu}$ ML: Genistein attenuates D-galactose-induced oxidative damage through decreased reactive oxygen species and $\mathrm{NF}-\kappa \mathrm{B}$ binding activity in neuronal PC12 cells. Life Sci 88: 82-88, 2011.

36. Yang JH, Hu JP, Rena K and Du NS: Structure-activity relationships of phenylethanoid glycosides in plants of Cistanche salsa on antioxidative activity. Zhong Yao Cai 32: 1067-1069, 2009 (In Chinese).

37. Gorina YV, Komleva YK, Lopatina OL, Volkova VV, Chernykh AI, Shabalova AA, Semenchukov AA, Olovyannikova RY and Salmina AB: The battery of tests for behavioral phenotyping of aging animals in the experiment. Adv Gerontol 30: 49-55, 2017 (In Russian).

38. Kumar DK, Choi SH, Washicosky KJ, Eimer WA, Tucker S, Ghofrani J, Lefkowitz A, McColl G, Goldstein LE, Tanzi RE and Moir RD: Amyloid- $\beta$ peptide protects against microbial infection in mouse and worm models of Alzheimer's disease. Sci Transl Med 8: 340ra372, 2016.

39. Cummings DM, Liu W, Portelius E, Bayram S, Yasvoina M, Ho SH, Smits H, Ali SS, Steinberg R, Pegasiou CM, et al: First effects of rising amyloid- $\beta$ in transgenic mouse brain: Synaptic transmission and gene expression. Brain 138: 1992-2004, 2015. 
40. Shelat PB, Chalimoniuk M, Wang JH, Strosznajder JB, Lee JC, Sun AY, Simonyi A and Sun GY: Amyloid beta peptide and NMDA induce ROS from NADPH oxidase and AA release from cytosolic phospholipase A2 in cortical neurons. J Neurochemi 106: 45-55, 2008.

41. Mattson MP, Barger SW, Begley JG and Mark RJ: Calcium, free radicals, and excitotoxic neuronal death in primary cell culture. Methods Cell Biol 46: 187-216, 1995.

42. Gai XY, Wei YH, Zhang W, Wuren TN, Wang YP, Li ZQ, Liu S, Ma L, Lu DX, Zhou Y and Ge RL: Echinacoside induces rat pulmonary artery vasorelaxation by opening the NO-cGMP-PKG-BKCa channels and reducing intracellular Ca2+ levels. Acta Pharmacol Sin 36: 587-596, 2015.

43. Hwang YP, Kim HG, Choi JH, Park BH, Jeong $\mathrm{MH}$ Jeong TC and Jeong HG: Acteoside inhibits PMA-induced matrix metalloproteinase-9 expression via CaMK/ERK- and JNK/NF- $\kappa \mathrm{B}$-dependent signaling. Mol Nutr Food Res 55 (Suppl 1): S103-S116, 2011.
44. Bencherif M: Pharmaceutical compositions for the prevention and treatment of central nervous system disorders. WO, pp.6468-6480, 2001.

45. Maelicke A, Samochocki M, Jostock R, Fehrenbacher A, Ludwig J, Albuquerque EX and Zerlin M: Allosteric sensitization of nicotinic receptors by galantamine, a new treatment strategy for Alzheimer's disease. Biol Psychiatry 49: 279-288, 2001.

46. Cheung TS, Song TH, Ng TB, Wu FH, Lao LX, Tang SC, Ho JC, Zhang KY and Sze SC: Therapeutic effects of herbal chemicals in traditional Chinese medicine on Alzheimer's disease. Curr Med Chem 22: 2392-2403, 2015. 